FACTA UNIVERSITATIS

Series: Economics and Organization Vol. 15, N ${ }^{\mathrm{o}} 4$, 2018, pp. 305 - 317

https://doi.org/10.22190/FUEO1804305A

Original Scientific Paper

\title{
NON-FINANCIAL BACKGROUND OF SUCCESS \\ AROUND GLOBAL FINANCIAL CRISIS - EVIDENCE FROM EASTERN EUROPE
}

\author{
UDC 338.124.4:330.526.33(4-11)
}

\section{Gyorgy Andor, Tamas Toth}

Eotvos Lorand University, Institute of Business Economics, Budapest, Hungary

\begin{abstract}
The research is about the relationship between the non-financial firm characteristics and the financial progress around the global financial crisis in 2008-2009. Non-financial firm characteristics data of 218 non-listed Central and Eastern European companies come from a survey in 2006 which focused on the capital budgeting practices and other characteristics of firms - such as presence of Western management culture, firm size, and extent of management ownership. The most important financial indicators are followed up reflecting these firms' financial progresses - sales, profit before tax, net income, earnings before interest and taxes, total assets, equity, debt, return on equity, return on assets and number of employees - from 2005 to 2012. To analyse firms' sensitivity to the 2008-2009 global financial crisis, differences of financial indicators between the pre-crisis (2005-2008) and post-crisis (2009-2012) periods are examined by the non-financial indicators.

Our results confirm that 1) firms using any accounting-based capital budgeting methods are less sensitive to the financial crisis; 2) small firms are more exposed to a volatile business environment than larger ones; and 3) firms with higher level of management ownership perform better in time of crisis than firms with lower level of management ownership.
\end{abstract}

Key words: capital budgeting practice; financial performance; Central and Eastern Europe; global financial crisis

JEL Classification: G31; G39; F23

Received July 31, 2018 / Revised October 19, 2018 / Accepted November 05, 2018

Corresponding author: Gyorgy Andor

Eotvos Lorand University, Institute of Business Economics, Budapest, 1053 Budapest, Szép utca 2, Hungary

E-mail: andor@gti.elte.hu 


\section{INTRODUCTION}

This paper focuses on the relationship between the financial success of firms around the 2008-2009 global financial crisis and their non-financial characteristics - such as the type of the applied capital budgeting methods, the presence of Western management culture, the firm size, and the extent of management ownership - in the Central and Eastern European (CEE) region.

Despite the fact that the theoretical background of capital budgeting is well-known and corporate finance courses have standard curriculum in it all over the world, we know much less about how companies apply those methods in practice. Furthermore, we know even less about how the use of these methods influences the financial performance of companies. And finally, it is also particularly interesting whether non-financial characteristics of firms determine the performance of companies, especially in an emerging economic environment around the time of a crisis.

Another study from the same authors, Andor and Toth (2018), deals with the progress of financial indicators in general, however not with the impact of the financial crisis in 2008-2009.

In this paper, the main research question is whether there are any differences in responsiveness to the crisis among firms using different capital budgeting techniques. Further questions related to financial sensitivity of companies are whether there is any impact of size, ownership and western management culture on responsiveness to crises among firms.

We have detailed data for several financial management features of 400 firms in ten CEE countries from Andor et al. (2015); those surveys were made around 2008. In this research, a narrower dataset of 218 companies is used with companies from nine CEE countries - Bulgaria, Croatia, the Czech Republic, Hungary, Latvia, Lithuania, Poland, Romania and Slovakia. Using the Amadeus database of Bureau Van Dijk, their most important financial indicators are followed up from 2005 to 2012. After having created general management and capital budgeting indicators (applied capital budgeting method, firm size, extent of executive ownership, and role of Western management culture) from the 2006 surveys, the statistical relationships between the firm characteristics indicators and the extent of changes in financial progress due to the 2008-2009 global financial crisis are analysed.

The rest of the paper proceeds as follows: after reviewing the relevant literature, Section 3 shows the dataset and the methodology used, while Section 4 discusses the results of the analyses. General conclusions are presented in Section 5.

\section{THEORETICAL BACKGROUND}

Values of companies, of course, are determined by their investment choices. Thus, the method by which companies choose their investment projects must have a crucial role. According to the general textbook approach, the discounted cash-flow (DCF) method is the proper one to maximize the value of the firm or the shareholder value of the firm. The basic concept of the DCF approach is that companies have to invest in projects which have positive expected profit, taking into consideration all costs, also including the cost of capital used by the projects. That is, the DCF approach treats the problem of time value of money. 
However, DCF is not the only method widely used by companies in practice. Two other generally widespread approaches must be considered: the accounting-based (AB) method and the (simple, not discounted) payback period (PP) method. Both of them ignore the time value of money which is the most relevant inaccuracy of those methods (Ross et al. 2010). On the other hand, AB and PP approaches have certain advantages, for so many firms apply them. In case of a loan agreement when solvency can be measured more safely by accounting based cash-flow plans, an $\mathrm{AB}$ method can be a better choice; and the payback method can be a more useful way of analysis when a company faces limited financial resources.

Nevertheless, the general absence of the DCF approach obviously seems to be a capital budgeting analysis mistake. Our research hypothesis is, therefore, that companies using the DCF approach have better financial performance, especially during hard times, during financial crises.

We know more and more about what capital budgeting methods companies are using around the world (Graham and Harvey (2001), Brounen et al. (2004), Arnold and Hatzopoulos (2000), Holmén and Pramborg (2009), Daunfeldt and Hartwig (2014), Liljeblom and Vaihekoski (2004), Hermes et al. (2007), Truong et al. (2008), Maquieira et al. (2012), Mendes-Da-Silva and Saito (2014), Correia and Cramer (2008), Singh et al. (2012), Kester et al. (1999), Hernadi and Ormos (2012), Andor et al. (2015)). Using the output of these articles as inputs to our analyses and using the time series of the financial data series of the companies concerned, we can compare business performance with different methods. (As there were limited number of listed companies among the companies involved in the study of Andor et al. (2015) (i.e. 1\% of the listed companies in the population and in the sample), the business performance can only be described by the development of accounting data instead of market price data.)

There is no clear evidence whether better performing companies are more likely to apply sophisticated capital budgeting practices than less well performing companies in difficult economic and financial circumstances. This study contributes to this field by answering the question in the case of firms in the CEE region: are there any differences in responsiveness to crises among firms using different capital budgeting techniques?

Small firm effect, i.e., smaller firms outperforming larger companies, is a well-known phenomenon among listed companies. One of the potential explanations is that smaller companies have a greater amount of growth opportunities than larger companies do. Another explanation is that small companies' business progresses tend to be more volatile, which can lead to lower prices and larger returns. E.g., Fama and French (1993) and Ferguson and Shockley (2003) show that the size effect can be confirmed for listed firms as a phenomenon reflecting a credit risk premium. The analysis of non-listed firms' financial progress may improve our understanding of the effects of size.

The ownership structure can also affect the financial progress of a firm. In the field of corporate governance, agency theory is well-known. The theory says that firms with widespread ownership structure face the problem that the company may deviate from value maximizing decisions because of the opportunistic behaviour of management (Andor and Toth, 2018).

In the CEE region, considering its post-communist past, an exciting question might be the following: is there a relationship between Western or local management culture and financial performance? It is conceivable that firms with a local management culture can adapt better to the local characteristics of the environment than firms with a Western 
management culture? On the other hand, rules and approaches of Western culture can lead to better financial performance even in a changing environment without strong capitalist roots.

The impact of Western management culture in less developed countries, particularly countries in the CEE region, is an area that has not been well studied. Wade and Parkhe (2012) found that a majority of joint foreign-local ventures in Hungary adopted the values, practices, and systems of their Western partners without clear advantages. A related study by von Weltzien Hoivik (2007) examined how culture has influenced the Chinese managers' perception of some Western management instruments, such as codes of ethics. The paper concluded that Western management systems and tools do not necessarily function equally well in Chinese culture unless they are reassessed and adapted. This study can contribute to the current body of knowledge by answering the following question: do companies with a Western management culture outperform companies with a local management culture around financial crisis?

\section{DATA AND METHODOLOGY}

\subsection{Sample firms}

The sample firms are drawn from the 400 firms examined by Andor et al. (2015). The examined population consists of those companies that have at least 25 employees and were stratified by country and company size. The 400 companies' data were obtained by random sampling in the subgroups.

For additional financial data we use the Amadeus database of Bureau Van Dijk, which covers all firms in Europe. The Amadeus database includes standardized annual accounts (consolidated and unconsolidated), financial ratios, sectoral activities and ownership data (Amadeus, 2015). We use unconsolidated data. From the 400 firms those were dropped that did not have complete dataset on sales, EBIT, total assets, equity, debt, ROE, ROA or on the number of employees in the Amadeus dataset for the period from 2005 to 2012. The drop rate did not differ significantly (by Kruskal-Wallis test) in the subgroups. The remaining 218 firms have their seats in 9 countries: 12 in Bulgaria, 13 in Croatia, 36 in Czech Republic, 14 in Hungary, 4 in Latvia, 10 in Lithuania, 77 in Poland, 38 in Romania, and 14 in Slovakia. This sample size offers 5\% margin of error with a 90\% confidence level.

To answer the research questions, we formed subgroups by company characteristics, like the used capital budgeting method, the role of the Western management culture, company size, and the extent of executive ownership. Then we analysed if there is a significant difference between the financial data of the subgroups in the pre- and post-crisis period. We consider that, although the data of company characteristics were measured around 2008, these data are quite static, as they reflect the company's decisions in the long run, and their change requires the active and compelling participation of owners and management.

\subsection{Financial indicators}

The created financial indicators are based on the Amadeus dataset from 2005 to 2012. 4 years are chosen before and after the financial crisis. Each financial indicator is calculated as an average of a firm's 4-4 years annual changes in the underlying accounting data. To 
analyse firms' sensitivity to crises, the differences of the financial indicators were calculated between the pre-crisis (2005-2008) and post-crisis (2009-2012) period. Figure 1 shows the timing aspects of the study.

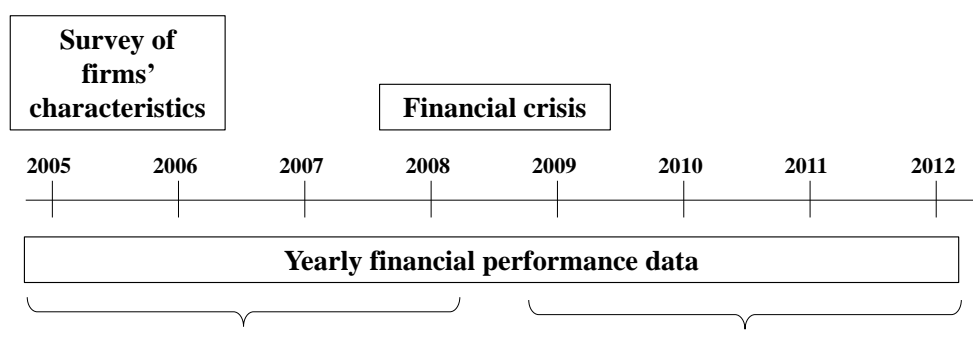

Fig. 1 Timing of the research.

The following financial indicators are defined:

- ' $\Delta$ Sales\%': The geometric average of the changes in a firm's annual time series of sales growth - difference between the pre-crisis (2005-2008) and post-crisis (20092012) periods.

- ' $\triangle$ EBIT\%': The standardized slope coefficient of a regression line fitted to a firm's annual EBIT series - difference between the pre-crisis (2005-2008) and post-crisis (2009-2012) periods.

- ' $\triangle \mathrm{ROE} '$ ' The arithmetic average of a firm's annual ROE time series - difference between the pre-crisis (2005-2008) and post-crisis (2009-2012) periods.

- ' $\triangle \mathrm{ROA}$ ': The arithmetic average of a firm's annual RAO time series - difference between the pre-crisis (2005-2008) and post-crisis (2009-2012) periods.

- ' $\Delta$ equity\%': The geometric average of the annual changes in a firm's equity series difference between the pre-crisis (2005-2008) and post-crisis (2009-2012) periods.

- ' $\Delta$ debt\%': The geometric average of the annual changes in a firm's debt series difference between the pre-crisis (2005-2008) and post-crisis (2009-2012) periods.

- ' $\Delta$ assets\%': The geometric average of the annual changes in a firm's total assets series - difference between the pre-crisis (2005-2008) and post-crisis (2009-2012) periods.

- ' $\Delta \mathrm{D} / \mathrm{A}$ ': The arithmetic average of a firm's annual debt to assets ratio series difference between the pre-crisis (2005-2008) and post-crisis (2009-2012) periods.

- ' $\Delta \mathrm{D} / \mathrm{A} \%$ ': The arithmetic average of the annual changes in a firm's debt to assets ratio series - difference between the pre-crisis (2005-2008) and post-crisis (2009-2012) periods.

- ' $\Delta \mathrm{E} / \mathrm{A}$ ': The arithmetic average of a firm's annual equity to assets ratio series difference between the pre-crisis (2005-2008) and post-crisis (2009-2012) periods.

- ' $\Delta \mathrm{E} / \mathrm{A} \%$ ': The arithmetic average of the annual changes in a firm's equity to assets ratio series - difference between the pre-crisis (2005-2008) and post-crisis (20092012) periods.

- ' $\triangle \mathrm{EMP \%} \%$ ' The geometric average of the annual changes in a firm's annual number of employees' time series - difference between the pre-crisis (2005-2008) and post-crisis (2009-2012) periods. 


\subsection{Capital budgeting practice indicators}

The original survey questionnaire used by Andor et al. (2015) contained several questions about different capital budgeting techniques. In this research, consolidated categories were made focusing only on DCF and $\mathrm{AB}$ techniques. Four categories were created, which are mutually exclusive and contain all firms. The definitions of the binary variables are the same as in Andor and Toth (2018):

- 'No formal technique': it is 0 if the company did not use any formal capital budgeting analysis, otherwise it is 1 .

- 'Frequent users of $\mathrm{AB}$ ' (AB): If a firm used frequently (always or almost always) any kind of accounting-based methods $(\mathrm{AB})$ only, such as accounting rate of return (ARR), return on investment (ROI), return on assets (RAO), simple earnings multiples, etc., it is 1 , otherwise it is 0 . The simple payback period (PP) was also in this category, since this method does not utilize a discounting technique.

- 'Frequent users of DCF' (DCF): Firms were asked whether they frequently (always or almost always) use any kind of discounted cash flow (DCF) technique such as net present value (NPV) or its variants, such as adjusted present value method (APV), equity cash flow method (ECF), free cash flow method (FCF), internal rate of return (IRR), profitability index (PI), etc. The discounted payback period (DPP) was also considered a type of DCF method. The variable is 1 if the firm answered yes (and do not use always or almost always $\mathrm{AB}$ methods), otherwise it is 0 .

- 'Frequent users of $\mathrm{AB}$ and $\mathrm{DCF}$ ' $(\mathrm{AB} \& \mathrm{DCF})$ : this variable is 1 if the firm reported using both $\mathrm{AB}$ and $\mathrm{DCF}$ technique for their investment decisions, otherwise it is 0 .

\subsection{Western management culture indicator}

To examine the role of the Western management culture, the following binary variable is created:

- 'Western management culture': This is 1 if the company reported dominance of a foreign management culture that was rooted in Western culture such as Western Europe, USA, or Canada; otherwise it is 0. (The original survey question was: "Which country's management culture dominates in your firm (besides the local one)?”)

\subsection{Other indicators}

The general management indicators are the company size, and the extent of executive ownership. The created binary variables for those are the following:

- 'Small size': This is 1 if a firm's number of employees is smaller than 250 (and with sales revenue and/or total assets below 50 million Euros); otherwise it is 0 .

- 'Low percentage of ownership': This is 1 if the management owns less than $10 \%$ of the company; otherwise it is 0 .

\subsection{Statistical tests}

The standard method for testing the difference between two means is the two-sample T-test. However, we reject the null hypothesis by Anderson-Darling Test that the financial performance indicators' distributions are normal at $10 \%$ significance level in all cases. Table 1 shows the descriptive statistics of financial indicators. 
Table 1 Descriptive statistic of financial indicators.

\begin{tabular}{lcrcccrcrr}
\hline Variable & Mean & StDev & Min & Q1 & Median & \multicolumn{1}{c}{ Q3 } & Max & Skewness & Kurtosis \\
\hline$\Delta$ Sales\% & -0.129 & 0.237 & -1.093 & -0.233 & -0.098 & -0.001 & 0.902 & -0.48 & 3.83 \\
$\Delta$ EBIT\% & -1.484 & 0.761 & -0.098 & -0.701 & -0.020 & 0.418 & 1.467 & 1.47 & -0.05 \\
$\Delta$ ROE & -0.098 & 0.272 & -1.646 & -0.190 & -0.045 & 0.015 & 1.172 & -1.06 & 9.39 \\
$\Delta$ ROA & -0.035 & 0.083 & -0.551 & -0.068 & -0.014 & 0.008 & 0.212 & -1.62 & 6.94 \\
$\Delta$ Equity\% & -0.167 & 0.365 & -2.291 & -0.272 & -0.125 & 0.015 & 1.294 & -1.81 & 10.56 \\
$\Delta$ Debt\% & -0.136 & 0.357 & -1.569 & -0.313 & -0.108 & 0.082 & 1.204 & -0.35 & 2.79 \\
$\Delta$ Assets\% & -0.130 & 0.221 & -1.156 & -0.250 & -0.093 & -0.006 & 0.870 & -0.71 & 4.94 \\
$\Delta($ D/A $\%$ & -0.022 & 0.126 & -0.375 & -0.093 & -0.025 & 0.051 & 0.363 & 0.14 & 0.86 \\
$\Delta($ E/A)\% & 0.022 & 0.126 & -0.362 & -0.051 & 0.025 & 0.093 & 0.375 & -0.14 & 0.86 \\
$\Delta$ EMP\% & -0.056 & 0.187 & -1.109 & -0.137 & -0.021 & 0.014 & 0.612 & -0.93 & 7.24 \\
\hline
\end{tabular}

Since the indicators are not normally distributed, the Mann-Whitney U-test can be used to compare the populations represented by the subsamples. All of the test's assumptions hold in all cases: the variables are measured on a continuous scale; the subgroups and the data in the subgroups are independent; and none of the variables is normally distributed.

\section{RESULTS}

4.1. Capital budgeting practice -

Did companies applying theoretically better capital budgeting methods have more positive/negative sensitivity to the financial crisis in 2008 ?

Table 2 shows the descriptive statistics of the changes of financial progress variables around the crisis in groups of firms using different capital budgeting techniques. The pvalues of pairwise Mann-Whitney U-tests are calculated between the financial progress changes results of firms using 'No formal' and using any sophisticated capital budgeting practices. Only those panels which contain significant results are shown.

Indicators reflecting sensitivity in Table 3 show interesting results. It seems that the $\mathrm{AB}$ user firms' growth rate of sales $(\Delta$ Sales $\%)$, total assets ( $\triangle$ Assets $\%)$ and debts $(\Delta \operatorname{Debt} \%)$ are less sensitive to an economic crisis than those of the ad-hoc firms' are. These differences are significant for the entire population only between $\mathrm{AB}$ and ad-hoc companies. The results support the intuitive expectation that firms with more stable sales growth rates can access credits easier, because stable sales growth rates lead to less risky credit metrics. Conversely, it is also a reasonable explanation that the advantages of easy credit access motivate the management to focus on stable accounting indicators.

It is a surprising result that the 'AB\&DCF' companies' $\triangle \mathrm{ROA}$ indicators show significant sensitivity as opposed to ad-hoc firms. Although firms using purely AB or DCF method show a less sensitive picture in the sample than mixed firms and more sensitive than ad-hoc firms, still, the Mann-Whitney's $\mathrm{H}_{0}$ cannot be rejected in either case. There are two possible explanations for the outstanding sensitivity of mixed firms. Combining two fundamentally different methods weakens the responsiveness of a firm because the potentially contradictory recommendations of different methods in a crisis situation further complicate the decision making process. On the other hand, it is conceivable that sensitive companies with volatile financial performance try to apply more diverse, more sophisticated methods to reduce the 
risk of deficient decisions. Additional research is needed to clarify which one is the relevant answer.

Table 2 Descriptive statistics of changes of financial variables around the crisis in 2008-2009 grouped by capital budgeting practice indicators, and p-values of Mann-Whitney U-tests between financial progress results of firms using 'No formal' and using other capital budgeting practices sets, from 2005 to 2012.

\begin{tabular}{|c|c|c|c|c|c|c|c|c|c|}
\hline Variable & $\mathrm{N}$ & Mean & StDev & Min & Q1 & Median & Q3 & Max & $\mathrm{P}$-value \\
\hline \multicolumn{10}{|c|}{ Panel B: $\Delta$ Sales $\%$} \\
\hline No formal & 45 & -0.17 & 0.28 & -0.83 & -0.31 & -0.09 & -0.01 & 0.69 & \\
\hline $\mathrm{AB}$ & 52 & -0.07 & 0.15 & -0.66 & -0.14 & -0.07 & 0.00 & 0.25 & $0.055^{*}$ \\
\hline DCF & 29 & -0.14 & 0.20 & -0.88 & -0.18 & -0.12 & -0.04 & 0.18 & 0.903 \\
\hline $\mathrm{AB} \& \mathrm{DCF}$ & 92 & -0.14 & 0.26 & -1.09 & -0.25 & -0.12 & 0.00 & 0.90 & 0.903 \\
\hline \multicolumn{10}{|c|}{ Panel E: $\triangle \mathrm{ROA}$} \\
\hline No formal & 45 & -0.024 & 0.072 & -0.292 & -0.040 & -0.005 & 0.010 & 0.100 & \\
\hline $\mathrm{AB}$ & 52 & -0.038 & 0.103 & -0.551 & -0.078 & -0.011 & 0.011 & 0.144 & 0.472 \\
\hline DCF & 29 & -0.019 & 0.070 & -0.183 & -0.044 & -0.010 & 0.015 & 0.118 & 0.748 \\
\hline $\mathrm{AB} \& \mathrm{DCF}$ & 92 & -0.043 & 0.079 & -0.241 & -0.082 & -0.022 & 0.004 & 0.212 & $0.064^{*}$ \\
\hline \multicolumn{10}{|c|}{ Panel F: $\Delta$ Assets $\%$} \\
\hline No formal & 45 & -0.156 & 0.161 & -0.477 & -0.296 & -0.138 & -0.035 & 0.070 & \\
\hline $\mathrm{AB}$ & 52 & -0.084 & 0.187 & -0.675 & -0.174 & -0.067 & 0.017 & 0.498 & $0.051^{*}$ \\
\hline DCF & 29 & -0.119 & 0.176 & -0.535 & -0.181 & -0.088 & -0.022 & 0.264 & 0.324 \\
\hline $\mathrm{AB} \& \mathrm{DCF}$ & 92 & -0.147 & 0.270 & -1.156 & -0.282 & -0.095 & 0.025 & 0.870 & 0.424 \\
\hline \multicolumn{10}{|c|}{ Panel G: $\Delta$ Debt $\%^{\circ}$} \\
\hline No formal & 45 & -0.192 & 0.303 & -1.055 & -0.353 & -0.140 & 0.039 & 0.256 & \\
\hline $\mathrm{AB}$ & 52 & -0.067 & 0.256 & -0.734 & -0.208 & -0.079 & 0.115 & 0.588 & $0.095^{*}$ \\
\hline DCF & 29 & -0.128 & 0.238 & -0.760 & -0.256 & -0.141 & 0.078 & 0.260 & 0.485 \\
\hline $\mathrm{AB} \& \mathrm{DCF}$ & 92 & -0.150 & 0.448 & -1.569 & -0.452 & -0.125 & 0.113 & 1.204 & 0.600 \\
\hline
\end{tabular}

The last column shows p-values of pairwise Mann-Whitney U tests calculated between the 'No formal technique' and the referred capital budgeting practice indicator. ${ }^{* * * * * *}$ means: the $\mathrm{H} 0$

(there's no difference in medians) can be rejected at the 10, 5, 1 percent significance level, respectively.

It should be mentioned that in the whole research there is only one significant difference between the financial indicators of $\mathrm{AB}$ and DCF firms. In the case of $\triangle \mathrm{Sales} \%$ the $\mathrm{p}$-value of the Mann-Whitney test between AB (-0.07) and DCF (-0.12) is 0.082. The explanation for this difference might be that firms with stable sales growth rate (and with moderate growth opportunities) tend to base their decision-making processes on accounting indicators, because a less volatile environment determines their long-term performance, and $A B$ indicators emphasize short-term efficiency over long-term performance. Besides, the research cannot prove any significant difference between companies using financial indicators of the $\mathrm{AB}$ and $\mathrm{DCF}$. As the dataset is from the CEE region where the DCF methods are used less often and the $\mathrm{AB}$ methods are used more often than in other regions of the world (see e.g. Andor et al., 2015), further research is needed to clarify whether this is a regional characteristic, or it is the case in general. 


\subsection{Western management culture - Did companies with Western management culture have more positive/negative sensitivity to the financial crisis in 2008?}

Table 3 shows the descriptive statistics of the financial indicators grouped by Western or local management culture.

Only the equity and assets growth $(\Delta$ Equity $\%, \Delta$ Assets $\%)$ of firms with Western management culture shows significantly less sensitivity to the crisis as opposed to companies with local style culture.

Table 3 Descriptive statistics of financial indicators separated by the type of management culture (2005-2012).

\begin{tabular}{lccccccccc}
\hline Variable & Wes. & Mean & StDev & Min & Q1 & Median & \multicolumn{1}{c}{ Q3 } & Max & P-Value \\
\hline$\Delta$ Sales\% & 1 & -0.131 & 0.210 & -1.093 & -0.235 & $\mathbf{- 0 . 1 0 9}$ & -0.001 & 0.390 & 0.651 \\
& 0 & -0.128 & 0.261 & -0.880 & -0.211 & $\mathbf{- 0 . 0 8 6}$ & -0.002 & 0.903 & \\
\hline$\Delta$ EBIT\% & 1 & -0.071 & 0.724 & -1.475 & -0.644 & $\mathbf{- 0 . 0 0 1}$ & 0.359 & 1.467 & 0.669 \\
& 0 & -0.122 & 0.795 & -1.484 & -0.791 & $\mathbf{- 0 . 0 2 3}$ & 0.593 & 1.134 & \\
\hline$\Delta$ ROE & 1 & -0.099 & 0.306 & -1.646 & -0.198 & $\mathbf{- 0 . 0 4 6}$ & 0.033 & 1.172 & 0.778 \\
& 0 & -0.097 & 0.240 & -1.232 & -0.177 & $\mathbf{- 0 . 0 4 3}$ & 0.008 & 0.977 & \\
\hline$\Delta$ ROA & 1 & -0.027 & 0.081 & -0.241 & -0.073 & $\mathbf{- 0 . 0 1 1}$ & 0.017 & 0.212 & 0.217 \\
& 0 & -0.041 & 0.085 & -0.551 & -0.064 & $\mathbf{- 0 . 0 1 7}$ & 0.003 & 0.144 & \\
\hline$\Delta$ Equity\% & 1 & -0.122 & 0.310 & -1.346 & -0.247 & $\mathbf{- 0 . 1 0 6}$ & 0.055 & 0.935 & $\mathbf{0 . 0 9 7}$ \\
& 0 & -0.207 & 0.406 & -2.291 & -0.294 & $\mathbf{- 0 . 1 4 6}$ & -0.010 & 1.294 & \\
\hline$\Delta$ Debt\% & 1 & -0.128 & 0.406 & -1.569 & -0.284 & $\mathbf{- 0 . 0 9 7}$ & 0.061 & 1.204 & 0.755 \\
& 0 & -0.143 & 0.308 & -1.055 & -0.317 & $\mathbf{- 0 . 1 1 3}$ & 0.095 & 0.702 & \\
\hline$\Delta$ Assets\% & 1 & -0.111 & 0.232 & -1.156 & -0.205 & $\mathbf{- 0 . 0 7 9}$ & 0.023 & 0.870 & $\mathbf{0 . 0 9 7}$ \\
& 0 & -0.148 & 0.209 & -1.109 & -0.276 & $\mathbf{- 0 . 1 0 6}$ & -0.030 & 0.498 & \\
\hline$\Delta$ (D/A)\% & 1 & -0.030 & 0.123 & -0.346 & -0.104 & $\mathbf{- 0 . 0 2 8}$ & 0.046 & 0.327 & 0.416 \\
& 0 & -0.016 & 0.130 & -0.375 & -0.082 & $\mathbf{- 0 . 0 1 5}$ & 0.056 & 0.363 & 0.346 \\
\hline$\Delta$ (E/A)\% & 1 & 0.030 & 0.123 & -0.327 & -0.046 & $\mathbf{0 . 0 2 8}$ & 0.104 & 0.346 & 0.416 \\
& 0 & 0.016 & 0.130 & -0.363 & -0.056 & $\mathbf{0 . 0 1 5}$ & 0.082 & 0.375 & 0.217 \\
\hline$\Delta$ EMP\% & 1 & -0.027 & 0.081 & -0.241 & -0.073 & $\mathbf{- 0 . 0 1 1}$ & 0.017 & 0.212 & 0.144 \\
\hline
\end{tabular}

W. cult.=1: Western management culture, $\mathrm{N}=103 ; \mathrm{W}$. cult. $=0$ : local management culture, $\mathrm{N}=115$. The last column shows the p-values of Mann-Whitney U tests. ${ }^{*}{ }^{* *},{ }^{* * *}$ means: the H0

(there's no difference in medians) can be rejected at the 10,5,1 percent significance level, respectively.

To conclude the above, the $\Delta$ Assets $\%$ and $\Delta$ Equity $\%$ paths of the firms with Western management culture are less sensitive to a crisis than those of the firms with local management culture. Although we did not find significant differences in any other financial indicators, the sample data suggest that firms with Western management culture tend to preserve operational efficiency, and try to decrease financial leverage in time of crisis.

\subsection{Size and executive ownership}

Table 4 shows the descriptive statistics of the financial indicators separated by the size of the firm. The p-values are the results of pairwise Mann-Whitney U tests. 
Table 4 Descriptive statistics of financial indicators separated by firm size (2005-2012).

\begin{tabular}{|c|c|c|c|c|c|c|c|c|c|}
\hline Variable & Size & Mean & StDev & Min & Q1 & Median & Q3 & Max & P-Value \\
\hline \multirow[t]{2}{*}{$\Delta$ Sales $\%$} & 1 & -0.169 & 0.220 & -0.827 & -0.275 & -0.130 & -0.034 & 0.390 & $0.093^{*}$ \\
\hline & 0 & -0.118 & 0.242 & -1.093 & -0.212 & -0.086 & 0.004 & 0.903 & \\
\hline \multirow[t]{2}{*}{$\Delta \mathrm{EBIT} \%$} & 1 & -0.340 & 0.763 & -1.484 & -1.061 & -0.297 & 0.086 & 1.467 & $0.006^{* * * *}$ \\
\hline & 0 & -0.028 & 0.748 & -1.475 & -0.682 & 0.021 & 0.487 & 1.429 & \\
\hline \multirow[t]{2}{*}{$\Delta \mathrm{ROE}$} & 1 & -0.149 & 0.156 & -0.523 & -0.253 & -0.124 & -0.035 & 0.252 & $0.001^{* * * *}$ \\
\hline & 0 & -0.084 & 0.296 & -1.646 & -0.153 & -0.025 & 0.027 & 1.172 & \\
\hline \multirow[t]{2}{*}{$\triangle \mathrm{ROA}$} & 1 & -0.054 & 0.069 & -0.292 & -0.090 & -0.028 & -0.011 & 0.041 & $0.005^{* * * *}$ \\
\hline & 0 & -0.029 & 0.086 & -0.551 & -0.062 & -0.008 & 0.012 & 0.212 & \\
\hline \multirow[t]{2}{*}{$\Delta$ Equity $\%$} & 1 & -0.209 & 0.247 & -0.787 & -0.377 & -0.212 & -0.072 & 0.697 & $0.004^{* * *}$ \\
\hline & 0 & -0.154 & 0.393 & -2.291 & -0.243 & -0.084 & 0.029 & 1.294 & \\
\hline \multirow[t]{2}{*}{$\Delta \mathrm{Debt}^{0} \%$} & 1 & -0.115 & 0.356 & -1.055 & -0.193 & -0.098 & 0.099 & 0.940 & 0.470 \\
\hline & 0 & -0.142 & 0.358 & -1.569 & -0.320 & -0.109 & 0.068 & 1.204 & \\
\hline \multirow[t]{2}{*}{$\Delta$ Assets $\%$} & 1 & -0.150 & 0.244 & -0.795 & -0.280 & -0.125 & -0.040 & 0.870 & 0.146 \\
\hline & 0 & -0.125 & 0.214 & -1.156 & -0.224 & -0.085 & 0.010 & 0.498 & \\
\hline \multirow[t]{2}{*}{$\Delta(\mathrm{D} / \mathrm{A}) \%$} & 1 & -0.039 & 0.125 & -0.316 & -0.111 & -0.057 & 0.025 & 0.334 & 0.190 \\
\hline & 0 & -0.018 & 0.127 & -0.375 & -0.086 & -0.019 & 0.056 & 0.363 & \\
\hline \multirow[t]{2}{*}{$\Delta(\mathrm{E} / \mathrm{A}) \%$} & 1 & 0.039 & 0.125 & -0.334 & -0.025 & 0.057 & 0.111 & 0.316 & 0.190 \\
\hline & 0 & 0.018 & 0.127 & -0.363 & -0.056 & 0.019 & 0.086 & 0.375 & \\
\hline \multirow[t]{2}{*}{$\Delta \mathrm{EMP} \%$} & 1 & -0.054 & 0.069 & -0.292 & -0.090 & -0.028 & -0.011 & 0.041 & $0.005^{* * * *}$ \\
\hline & 0 & -0.029 & 0.086 & -0.551 & -0.062 & -0.008 & 0.012 & 0.212 & \\
\hline
\end{tabular}

Size=1: small firms, $\mathrm{N}=49$; Size=0: large and medium firms, $\mathrm{N}=169$. The last column shows the $\mathrm{p}$-values of Mann-Whitney U tests. ${ }^{* * *}{ }^{* * * *}$ means: the H0 (there's no difference in medians) can be rejected at the $10,5,1$ percent significance level, respectively.

The difference of sales growth in pre- and post-crisis period $(\Delta$ Sales $\%)$ is $-13 \%$ in small companies, while $-8.6 \%$ in large firms. The difference of EBIT growth $(\triangle \mathrm{EBIT} \%)$ in pre- and post-crisis period is $-29.7 \%$ in small companies, while $2.1 \%$ in large firms. It seems that size effect not affects operational efficiency, but small firms' sales and EBIT growth are more sensitive to a crisis than those of the large firms.

The difference of ROE and RAO in pre- and post-crisis period ( $\triangle \mathrm{ROE}$ and $\triangle \mathrm{ROA})$ is significantly higher in small firms, which suggests that small firms are more exposed to a volatile business environment. Small firms seem to use mainly equity instead of loans to react to the changes of the economic environment.

Table 5 shows the descriptive statistics of financial indicators grouped by the extent of management ownership.

The negative difference of sales, ROE, ROA, equity, and total assets growth in the pre- and post-crisis period is significantly higher in those firms where the percentage of the management ownership is high. This suggests that firms with high percentage of management ownership performs better in a volatile market environment than firms with low percentage of management ownership and where the management uses the owners' equity to finance daily operations. 
Table 5 Descriptive statistics of financial indicators separated by the extent of management ownership (2005-2012).

\begin{tabular}{|c|c|c|c|c|c|c|c|c|c|}
\hline Variable & Own. & Mean & StDev & Min & Q1 & Median & Q3 & Max & P-Value \\
\hline \multirow[t]{2}{*}{$\Delta$ Sales $\%$} & 1 & -0.117 & 0.239 & -1.093 & -0.213 & -0.089 & 0.005 & 0.903 & $0.015^{* *}$ \\
\hline & 0 & -0.219 & 0.209 & -0.808 & -0.329 & -0.140 & -0.063 & -0.004 & \\
\hline \multirow[t]{2}{*}{$\overline{\Delta \mathrm{EBIT} \%}$} & 1 & -0.041 & 0.760 & -1.475 & -0.683 & 0.012 & 0.496 & 1.467 & $0.002^{* * * 4}$ \\
\hline & 0 & -0.520 & 0.636 & -1.484 & -1.101 & -0.433 & -0.043 & 1.091 & \\
\hline \multirow[t]{2}{*}{$\Delta \mathrm{ROE}$} & 1 & -0.091 & 0.283 & -1.646 & -0.178 & $\begin{array}{l}-0.036 \\
\end{array}$ & 0.020 & 1.172 & $\mathrm{0.011}^{* *}$ \\
\hline & 0 & -0.155 & 0.166 & -0.462 & -0.266 & -0.167 & -0.041 & 0.252 & \\
\hline \multirow[t]{2}{*}{$\triangle \mathrm{ROA}$} & 1 & -0.032 & 0.084 & -0.551 & -0.063 & -0.011 & 0.010 & 0.212 & $0.053^{* *}$ \\
\hline & 0 & -0.056 & 0.074 & -0.292 & -0.088 & -0.036 & -0.010 & 0.041 & \\
\hline \multirow[t]{2}{*}{$\Delta$ Equity $\%$} & 1 & -0.153 & 0.381 & -2.291 & -0.246 & -0.102 & 0.026 & 1.294 & $0.001^{* * * *}$ \\
\hline & 0 & -0.268 & 0.189 & -0.723 & -0.387 & -0.276 & -0.122 & 0.067 & \\
\hline \multirow[t]{2}{*}{$\Delta \mathrm{Debt}^{\%} \%$} & 1 & -0.127 & 0.353 & -1.569 & -0.297 & -0.106 & 0.078 & 1.204 & 0.579 \\
\hline & 0 & -0.201 & 0.388 & -1.055 & -0.535 & -0.146 & 0.094 & 0.388 & \\
\hline \multirow[t]{2}{*}{$\Delta$ Assets $\%$} & 1 & -0.117 & 0.218 & -1.156 & -0.203 & -0.080 & 0.007 & 0.870 & $0.012^{* *}$ \\
\hline & 0 & -0.226 & 0.218 & -0.795 & -0.370 & -0.191 & -0.061 & 0.158 & \\
\hline \multirow[t]{2}{*}{$\Delta(\mathrm{D} / \mathrm{A}) \%$} & 1 & -0.020 & 0.128 & -0.375 & -0.089 & -0.025 & 0.054 & 0.363 & 0.532 \\
\hline & 0 & -0.040 & 0.113 & -0.314 & -0.144 & -0.028 & 0.036 & 0.163 & \\
\hline \multirow[t]{2}{*}{$\Delta(\mathrm{E} / \mathrm{A}) \%$} & 1 & 0.020 & 0.128 & -0.363 & -0.054 & 0.025 & 0.089 & 0.375 & 0.532 \\
\hline & 0 & 0.040 & 0.113 & -0.163 & -0.036 & 0.028 & 0.144 & 0.314 & \\
\hline \multirow[t]{2}{*}{$\triangle \mathrm{EMP} \%$} & 1 & -0.032 & 0.084 & -0.551 & -0.063 & -0.011 & 0.010 & 0.212 & $0.053^{*}$ \\
\hline & 0 & -0.056 & 0.074 & -0.292 & -0.088 & -0.036 & -0.010 & 0.041 & \\
\hline
\end{tabular}

Ownership=1: low management ownership, N=192; Ownership=0: high management ownership, N=26. The last column shows the p-values of Mann-Whitney U tests. ${ }^{* * * * * *}$ means: the H0

(there's no difference in medians) can be rejected at the 10, 5, 1 percent significance level, respectively.

\section{CONCLUSIONS}

The research provides evidence on the relation between firms' non-financial characteristics and financial performance around the financial crisis in 2008-2009 - carried out in 218 firms in the Central and Eastern European region.

The results confirm that firms using any accounting-based capital budgeting methods were less sensitive to the financial crisis. However, firms using both $\mathrm{AB}$ and DCF methods did not have any advantage against ad-hoc firms. There are two possible explanations. Combining two fundamentally different methods weakens the responsiveness of a firm because the potentially contradictory recommendations of different methods in a crisis situation further complicates the decision making process. On the other hand, it is conceivable that sensitive companies with volatile financial performance try to apply more diverse, more sophisticated methods to reduce the risk of deficient decisions. Additional research is needed to clarify which one of the above is the relevant answer.

The results show that small firms are more exposed to a volatile business environment than larger ones. This supports the theory of small firm effect. However, this result applies to non-listed companies, while the small firm effect can be interpreted in the research field of Capital Asset Pricing Model. Exploring the exact context requires further research, though. 
Finally, the results confirm that firms with high percentage of management ownership perform better in time of crisis than firms with low percentage of management ownership. This result supports the theory of agency costs. If the owners have a strong influence on company decisions, then their interests are less affected.

Acknowledgement: Some parts of this paper have been presented at the $2^{\text {nd }}$ International Scientific Conference-EMAN 2018 (www.eman-conference.org).

\section{REFERENCES}

Amadeus. (2015). European Company Data, European University Institute. http://www.eui.eu/Research/ Library/ResearchGuides/Economics/Statistics/DataPortal/Amadeus.aspx, June.

Andor, Gy. \& Toth, T. (2018). Non-financial background of financial performance: Evidence from Central and Eastern Europe. 25th Annual Multinational Finance Society Conference, Budapest, Hungary, June 24-27

Andor Gy., Toth, T. \& S. Mohanty. (2015). Capital Budgeting Practices: A Survey of Central and Eastern European Firms. Emerging Markets Review.

Arnold, G. \& Hatzopoulos, P. (2000). The theory-practice gap in capital budgeting: Evidence from the United Kingdom. Journal of Business Finance and Accounting, 27, 603-26.

Brounen, D., De Jong, A. \& Koedijk, K. (2004). Corporate finance in Europe: Confronting theory with practice. Financial Management 33 (4), 71-101.

Correia, C. \& Cramer, P. (2008). An analysis of cost of capital, capital structure and capital budgeting practices: A survey of South African listed companies. Meditari Accountancy Research, 16 (2), 31-52.

Daunfeldt, S-O. \& Hartwig, F. (2014). What Determines the Use of Capital Budgeting Methods? Evidence from Swedish Listed Companies. Journal of Finance and Economics, 2 (4), 101-112.

Fama, E.F. \& French, K.R. 1993. Common risk factors in the returns on stocks and bonds. Journal of financial economics, 33 (1), 3-56.

Ferguson, M.F. \& Shockley, R.L. (2003). Equilibrium “anomalies”. The Journal of Finance, 58 (6), 2549-2580.

Graham, J. \& Harvey, C. (2001). The theory and practice of corporate finance: Evidence from the field. Journal of Financial Economics 60 (2), 187-243.

Hazen, G.B. (2003). A new perspective on multiple internal rates of return. The Engineering Economist, 48 (1), $31-51$.

Hermes, N., Smid, P. \& Yao, L. (2007). Capital budgeting practices: A comparative study of the Netherlands and China. International Business Review, 16 (5), 630-654.

Holmén, M. \& Pramborg, B. (2009). Capital budgeting and political risk: Empirical evidence. Journal of International Financial Management \& Accounting, 20, 105-134.

Hernádi, P. \& Ormos, M. (2012). Capital Structure and Its Choice in Central and Eastern Europe. Acta Oeconomica, 62 (2), 229-263.

Kester, G., Chang, R.P., Echanis, E.S., Haikal, S., Isa, M., Skully, M.T, Tsui, K.C. \& Wang, C.J. (1999). Capital budgeting practices in the Asia-Pacific region: Australia, Hong Kong, Indonesia, Malaysia, Philippines, and Singapore. Financial Practice and Education, 9 (1), 25-33.

Liljeblom, E. \& Vaihekoski, M. (2004). Investment evaluation methods and required rate of return in Finnish publicly listed companies. Finnish Journal of Business and Economics, 54, 9-24.

Maquieira, C.P., Preve, L.A. \& Sarria-Allende, V. (2012). Theory and practice of corporate finance: Evidence and distinctive features in Latin America. Emerging Markets Review, 13 (2), 118-148.

Mendes-Da-Silva, W. \& Saito, R. (2014). Stock Exchange Listing Induces Sophistication of Capital Budgeting. Revista de Administração de Empresas, 54 (5), 560-574.

Osborne, M.J. (2010). A resolution to the NPV-IRR debate?. The Quarterly Review of Economics and Finance, 50 (2), 234-239.

Ross, S.A., Westerfield, R.W. and Jordan, B.D. (2010). Fundamentals of Corporate Finance. Tata McGraw Hill Education, Inc., New York.

Singh, S., Jain, P.K. \& Yadav, S.S. (2012). Capital budgeting decisions: evidence from India. Journal of Advances in Management Research, 9 (1), 96-112.

Truong G., Partington, G. \& Peat, M. (2008). Cost of capital estimation and capital budgeting practice in Australia. Australian Journal of Management, 33, 1-6. 
Wade M.D. \& Parkhe, A. (2012). Hungarian-Western Partnerships: A Grounded Theoretical Model of Integration Processes and Outcomes. Journal of International Business Studies, 33 (3), 423-455.

Weber, T.A. (2014). On the (Non-) Equivalence of IRR and NPV. Journal of Mathematical Economics, 52, 25-39. Von Weltzien Hoivik, H. (2007). East Meets West: Tacit Messages about Business Ethics in Stories Told by Chinese Managers. Journal of Business Ethics, 74 (4), 457-469.

\section{NE-FINANSIJSKI OSNOV USPEHA U VREME GLOBALNE FINANSIJSKE KRIZE - PRIMERI IZ ISTOČNE EVROPE}

Istraživanje se bavi odnosom između ne-finansijskih karakteristika firmi i finansijskim napretkom u vreme globalne finansijske krize 2008-2009. Podaci o ne-finanskijskim karakteristikama 218 firmi koje se ne kotiraju na berzi iz Srednje i Istočne Evrope dobijeni sun a osnovu ankete sprovedene u 2006. godini, koja se fokusirala na prakse budžetskog finansiranja i druge karakteristike firmi - kao što su prisustvo zapadnjačkog modela upravljanja, veličina firme i stepen vasništva menadžmenta. Prate se ajvažniji finansijski indikatori koji odražavaju finansijski napredak ovih firmi -prodaja, dobit pre oporezivanja, neto prihod, dobit pre kamate i poreza, ukupna aktiva, kapital, dug, povrat na kapital, prinos na aktivu i broj zaposlenih - od 2005. do 2012. Da bi se analizirala osetljivosat firme na globalnu finansijksu krizu 2008-2009, istraživane su razlike između perioda pre krize (2005-2008) i posle nje (2009-2012) uz pomoć ne-finansijskih indikatora.

Naši rezultati potvrđuju da 1) firme koje koriste bilo koju metodu računovodstveno-zasnovanog kapitalnog budžetiranja su manje osetljive na finansijsku krizu; 2) male firme su izloženije nestalnom poslovnom okruženju od velikih; 3) firme sa većim nivoom upravljanja vlasništvom imaju bolje performance u vremenu krize od onih sa nižim nivoom upravljanja vlasništvo.

Ključne reči: praksa kapitalnog budžetiranja; finansijske performance; Srednja i Istočna Evropa; globalna finansijska kriza 